\title{
WAVELET ANALYSIS AND SENSING THE TOTAL OZONE CONTENT IN THE EARTH ATMOSPHERE: MYCROS TECHNOLOGY “GEOMATH”
}

\author{
A. V. Glushkov, V. N. Khokhlov, A. A. Svinarenko, \\ Yu. Ya. Bunyakova, G. P. Prepelitsa \\ Institute of Applied mathematics, P.O.Box 108, Odessa-9, 65009, Ukraine \\ E-mail: glushkov@paco.net
}

\begin{abstract}
WAVELET ANALYSIS AND SENSING THE TOTAL OZONE CONTENT IN THE EARTH ATMOSPHERE: MYCROS TECHNOLOGY "GEOMATH"

\section{A. V. Glushkov, V. N. Khokhlov, A. A. Svinarenko, Yu. Ya. Bunyakova, G. P. Prepelitsa}

It is carried out the mycros computer data processing technology for sensing the total ozone content in the Earth atmosphere, based on the using technical devices observation data and the joint wavelet analysis PC programs complex "GeoMath". As example of application, an influence of the Antarctic Oscillation on the total ozone content in the Southern Hemisphere is stuided by using the non-decimated wavelet transform. It is shown that the cycles of the Antarctic Oscillation with periods of 5.5, 3-4, 2-3, and 1 year have greatest wavelet power. The positive correlation dependence between the 5.5-year period of the Antarctic Oscillation Index and the mid-latitude total ozone is disclosed.
\end{abstract}

Key words: mycros computer technology "GeoMath", wavelet analysis , sensing the total ozone content

\section{Резюме \\ ВЕЙВЛЕТ АНАЛІЗ І ДЕТЕКТУВАННЯ ЗАГАЛЬНОГО ВМІСТУ ОЗОНУ У ЗЕМНІЙ АТМОСФЕРI: МІКРОС ТЕХНОЛОГІЯ “GЕОМАТН"}

\section{О. В. Глуиков, В. М. Хохлов, А. А. Свинаренко,} Ю. Я. Бунякова, Г. П. Препелица

Розроблено мікрос технологію обробки данних і детектування загального вмісту озону в земній атмосфері, яка базується на використанні данних супутникових тощо спостережень та ПК комплексу програм вейвлет аналізу “GeoMath". Як приклад застосування, вивчається вплиа антарктичної осциляції на загальний вміст озону у південній півкулі 3 використанням вейвлет трансформації. Показано, що наибільша вейвлет міцність спостерігається для циклів антарктичної осциляції з періодами 5.5, 3-4, 2-3 и 1 рік. Виявлено позитивну кореляцію між індексом антарктичної осциляції з 5.5-річним періодом та вмістом озону у середніх широтах.

Ключові слова: мікрос технологія “GeoMath”, вейвлет аналіз, детектування загального вмісту озону 


\title{
Резюме \\ ВЭЙВЛЕТ АНАЛИЗ И ДЕТЕКТИРОВАНИЕ ОБЩЕГО СОДЕРЖАНИЯ ОЗОНА В ЗЕМНОЙ АТМОСФЕРЕ: МИКРОС ТЕХНОЛОГИЯ "GЕОМАТН"
}

\author{
А. В. Глуиков, В. Н. Хохлов, А. А. Свинаренко, \\ Ю. Я. Бунякова, Г. П. Препелица
}

\begin{abstract}
Разработана микрос технология обработки данных и детектирования общего содержания озона в земной атмосфере, базирующаяся на использовании данных спутниковых и др. наблюдений и ПК комплексе программ вэйвлет анализа “GeoMath". В качестве примера применения, изучается влияние антарктической осцилляции на общее осдержание озона в южном полушарии с использованием вэйвлет преобразования. Показано, что наибольшая вейвлет мощность наблюдается для циклов антарктической осцилляции с периодами 5.5, 3-4, 2-3 и 1 год. Обнаружена положительная корреляция между индексом антарктической осцилляции с 5.5-летним периодом и содержанием озона в средних широтах.
\end{abstract}

Ключевые слова: микрос технология “GeoMath", вэйвлет анализ, детектирование общего содержания озона

\section{Introduction}

Carrying out new, avanced sensors and mycrosystems technologies in the modern atmosphere and environmental physics is related to ine of the most important problems. Here we present an advanced mycros data processing technology for sensing the total ozone content in the Earth atmosphere, based on the using technical devices observation data and the joint wavelet analysis PC programs complex "GeoMath" [1-5]. As example of application, an influence of the Antarctic Oscillation on the total ozone content in the Southern Hemisphere is stuided by using the non-decimated wavelet transform.

During the past one hundred years, much attention has been given to low-level atmospheric circulation for understanding the local to planetary scale climatic anomalies. During the 1920-1930s, a comprehensive study on atmospheric oscillations was carried out by Sir Gilbert Walker. Three oscillations were revealed and named as "North Atlantic Oscillation", "North Pacific Oscillation" and "Southern Oscillation". A large number of papers about these oscillations were published after Walker, and more details on their spatiotemporal variability were also revealed (see e.g. [6-8]). During the last two decades only, more comprehensive data over the Southern Hemisphere became available, and more analyses were carried out (see [8-10]). A fourth atmospheric oscillation in the middle and high southern latitudes was found $[9,10]$ and named as the Antarctic Oscillation (AAO). Gong \&Wang [9-10] have proposed the procedure to calculate the AAO Index (AAOI). The term AAO refers to a large scale alternation of atmospheric mass between the mid-latitude surface pressure and high latitudes surface pressure.Since the new reanalysis data was appeared [11], an opportunity offered for investigating the dynamics of atmospheric processes in the Southern Hemisphere as a whole and over the Antarctic in particular. However, most reliable data to the south of $50^{\circ} \mathrm{S}$ exists since the 1979 only when satellites were used to obtain various meteorological data. In spite of the fact that the NCEP-NCAR reanalysis covers the period starting with the 1948, the usefulness of Antarctic analysis in the NCEP-NCAR reanalysis before the satellite era is very questioned [12]. To reveal the lowfrequency periodicities of the AAO phase we use the wavelet decomposition. Also, using the wavelet analysis we show the relationship between these low-frequency variations of AAOI and total ozone (TO) in the mid-latitudes and tropics of the Southern Hemisphere. The fact that the atmospheric circulation determines substantially the variability of lowstratospheric TO and modulates its secular trends is well known [13]. In particular, the positive phase of the AAO can be the cause of Antarctic TO decreasing on 25 Dobson Unit.

\section{Methods and data}

\subsection{Non-decimated wavelet transform}

Since last decades, many scientists use the new powerful tool based on the wavelet decomposition for analyzing various signals. One can say without exaggeration, the wavelets has made revolution in both theory and practice of nonstationary signal processing. At present, the family of analysing func- 
tion dubbed wavelets is being increasingly used in problems of pattern recognition; in processing and synthesising various signals, speech for instance; in analysis of images of any kind (these may be iris images, X-ray picture of a kidney, satellite images of clouds or a planet surface, an image of mineral, etc.); for study of turbulent fields, for contraction (compression) of large volumes of information, and in many other cases.Some ideas of the wavelet theory were partially developed a long time ago. For instance, A. Haar published as far back as a 1910 the complete orthonormal system of basis function with the local domain of definition, which are now named as Haar's wavelets. However one can note that probably first mention about wavelets has appeared in the literature on digital processing and analysing of geophysical signals and meteorological time series [1417]. For detail about wavelet theory, the monograph of Daubechies [16] can be recommended.

Wavelets are fundamental building block functions, analogous to the trigonometric sine and cosine functions. Fourier transform extracts details from the signal frequency, but all information about the location of a particular frequency within the signal is lost. As a case in point, Figure 1 shows two periodograms for the AAOI starting with the 1948 (Fig. 1a) and with the 1979 (Fig. 1b). As is obvious, the structures of signal differ significantly from each other and main difference consists in the absent of peaks for the spectral power at the periodicities of 3 and 4 years in the case of shorter series which is while more reliable one. On the one hand, this can be caused by the modification of the AAO dynamics, but on the other hand the uncertainty of data till the 1979 affects adversely. Fourier transform not determines exactly the ground for these distinctions. From aforesaid, at the expense of their locality the wavelets have advantages over Fourier transform when nonstationary signals are analyzed. Here, we use non-decimated wavelet transform that has tem-
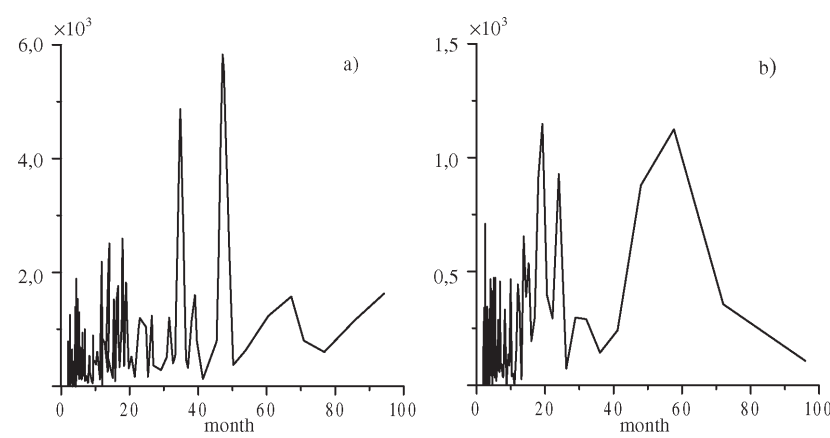

Figure 1. Periodograms of the AAO indices for periods since 1948 (a) and 1979 (b). poral resolution at coarser scales and allows to isolate time series of the major components of meteorological signals in a direct way (see [17-20]).

The dilation and translation of the mother wavelet $\psi(t)$ generates the wavelet as follows: $\psi_{j, k}(t)=2^{j /}$ ${ }^{2} \psi\left(2^{j} t-k\right)$. The dilation parameter $j$ controls how large the wavelet is, and the translation parameter $k$ controls how the wavelet is shifted along the $t$-axis. For a suitably chosen mother wavelet $\psi(t)$, the set $\left\{\psi_{j, k}\right\}_{j, k}$ provides an orthogonal basis, and the function $f$ which is defined on the whole real line can be expanded as

$$
f(t)=\sum_{k=-\infty}^{\infty} c_{0 k} \varphi_{0, k}(t)+\sum_{j=1}^{J} \sum_{k=-\infty}^{\infty} d_{j k} \psi_{j, k}(t),
$$

where the maximum scale $J$ is determined by the number of data, the coefficients $c_{0 k}$ represent the lowest frequency smooth components, and the coefficients $d_{j k}$ deliver information about the behaviour of the function $f$ concentrating on effects of scale around $2^{-j}$ near time $k \times 2^{-j}$. This wavelet expansion of a function is closely related to the discrete wavelet transform (DWT) of a signal observed at discrete points in time. In practice, the length of the signal, say $n$, is finite and, for our study, the data are available monthly, i.e. the function $f(t)$ in Eq. (1) is now a vector $f=\left(f\left(t_{1}\right), \ldots, f\left(t_{n}\right)\right)$ with $t_{i}=i / n$ and $i=1, \ldots, n$. With these notations, the DWT of a vector $f$ is simply a matrix product $d=W f$, where $d$ is an $n \times 1$ vector of discrete wavelet coefficients indexed by 2 integers, $d_{j k}$, and $W$ is an orthogonal $n \times n$ matrix associated with the wavelet basis. For computational reasons, it is simpler to perform the wavelet transform on time series of dyadic (power of 2) length. One particular problem with DWT is that, unlike the discrete Fourier transform, it is not translation invariant. This can lead to Gibbs-type phenomena and other artefacts in the reconstruction of a function. The non-decimated wavelet transform (NWT) of the data $\left(f\left(t_{1}\right), \ldots, f\left(t_{n}\right)\right)$ at equally spaced points $t_{i}=$ $i / n$ is defined as the set of all DWT's formed from the $n$ possible shifts of the data by amounts $i / n ; i=$ $1, \ldots, n$. Thus, unlike the DWT, there are $2^{j}$ coefficients on the $j$ th resolution level, there are $n$ equally spaced wavelet coefficients in the NWT: $d_{j k}=n^{-1} \sum_{i=1}^{n} 2^{j / 2} \psi\left[2^{j}(i / n-k / n)\right] y_{i}, k=0, \ldots, n-$ 1 , on each resolution level $j$. This results in $\log _{2}(n)$ coefficients at each location. As an immediate consequence, the NWT becomes translation invariant. Due to its structure, the NWT implies a finer sampling rate at all levels and thus provides a better ex- 
ploratory tool for analyzing changes in the scale (frequency) behaviour of the underlying signal in time. These advantages of the NWT over the DWT in time series analysis are demonstrated in Nason et al [18]. As in the Fourier domain, it is important to assess the power of a signal at a given resolution. In order to reach this goal, a time-domain model for encapsulating localized scale activity was proposed by Nason et al. An evolutionary wavelet spectrum (EWS) quantifies the contribution to process variance at the scale $j$ and time $k$. From the above paragraphs, it is easy to plot any time series into the wavelet domain. Another way of viewing the result of a NWT is to represent the temporal evolution of the data at a given scale. This type of representation is very useful to compare the temporal variation between different time series at a given scale. To obtain such results, the smooth signal $S_{0}$ and the detail signals $D_{j}(j=1, \ldots, J)$ are defined as follows

$$
S_{0}(t)=\sum_{k=-\infty}^{\infty} c_{0 k} \varphi_{0, k}(t) \text { and } D_{j}(t)=\sum_{k=-\infty}^{\infty} d_{j k} \psi_{j, k}(t)
$$

The fine scale features (high frequency oscillations) are captured mainly by the fine scale detail components $D_{J}$ and $D_{J-1}$. The coarse scale components $S_{0}, D_{1}$, and $D_{2}$ correspond to lower frequency oscillations of the signal. Note that each band is equivalent to a band-pass filter. Further we use the Daubechies wavelet (db15) as mother wavelet. This wavelet is biorthogonal and supports discrete wavelet transform.

\subsection{The $A A O$ index and total ozone}

Gong \& Wang [10] calculated the AAO index as the difference of normalized zonal-mean pressures at the $40^{\circ} \mathrm{S}$ and $60^{\circ} \mathrm{S}$. Here, we define the AAO index by the sea-level pressure anomalies to the south of $20^{\circ} \mathrm{S}$, i.e the Antarctic Oscillation is considered as the counterpart of Arctic Oscillation in the Northern Hemisphere. For calculations we use the NCEPNCAR reanalysis [11]. Since there is the restriction of dyadic length for time series applied to the NWT, we use the data from the May 1961 to the December $2003\left(2^{9}=512\right.$ months $)$. Figure 2 shows that the negative phase of the AAO prevailed during the 1960s, but starting with end of 1980s the positive phase of the AAO was predominating.

Systematic data on the total ozone in the Southern Hemisphere became available only after the Nimbus 7 was launched (November 1978). In the present work, owing to aforesaid limitations, we use data from the September 1982 to the April $1993\left(2^{7}=\right.$ 128 months). Also, the results of the Global Ozone Monitoring Experiment (GOME) are utilized, which are available still the August 1995; the data from January 1998 to April $2003\left(2^{6}=64\right.$ months $)$ are here used. Note that the agreement between the satellite data and ground-based ones is very high [20]

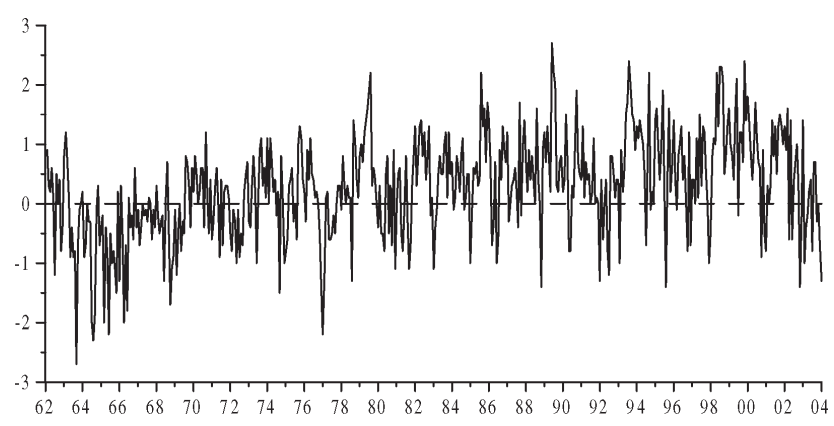
Figure 2. The AAO indices since January 1962 to December 2003.

\section{Results and discussion}

\subsection{The AAO phase variations}

At the present time, the information on the lowfrequency periodicities of the AAOI is scanty (e.g. the 45.7-month period documented by Gong \& Wang, 1999). In most cases, this is conditioned by the insufficiency of reliable data at the Southern high-latitudes.

Using the non-decimated wavelet transform, describe the main components of variability for the Antarctic oscillation by the methods determined in Section 2.1. Figure 3 shows the detail components $D_{4}-D_{7}$, which have the maxima of spectral power (see Fig. 1). The component $D_{4}$ has the period of 5.5-year, $D_{5}-3$-4-year, $D_{5}-2$-3-year, and $D_{5}-$ 1 -year. As is obvious, the greatest variations of the AAOI are registered for the components $D_{6}$ and $D_{7}$. Also, Figure 3 displays the advantages of the wavelet transform over Fourier transform. In particular, it shows clearly that starting with the 1980s the structure of fluctuations with the 3-4-year period $\left(D_{5}\right)$ altered profoundly. This explains the absent of power maxima for these cycles on Fig. 1a. It is naturally that the amplitude of these low-frequency fluctuations is varied (sometimes significantly) during the whole period under consideration. For example, during the 1960s, when the negative AAO phase was dominating, the amplitude of fluctuations for the detail components $D_{6}$ and $D_{7}$ was moderate. 


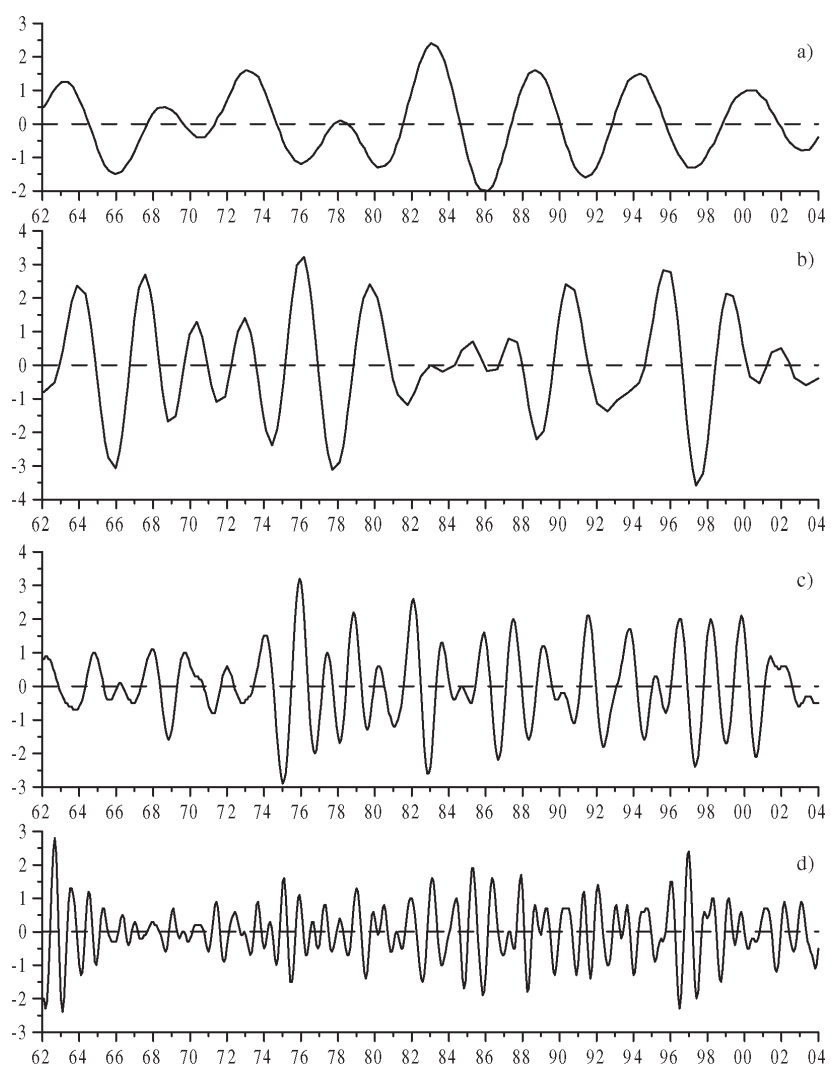

Figure 3. Detail components of the AAO indices: a) $\left.\left.\left.D_{4}, \mathrm{~b}\right)-D_{5}, \mathrm{c}\right)-D_{6}, \mathrm{~d}\right)-D_{7}$.

\subsection{The AAO impact of total ozone}

In the high-latitude stratosphere the low ozone content occurs in the case of the positive AAO phase. The low ozone content can be also resulted by the decreasing of activity in the stratospheric mean Lagrange circulation (also known as the Brewer-Dobson circulation) transporting the ozone from the tropical stratosphere to the poles. The annual cycle of Antarctic ozone content is characterized by its depletion in the August-September. According to the GOME data, such regime was violated only one time in the 2002, when the rarely vigorous negative AAO phase was observed during the October. The fact that just meteorological conditions caused the increasing of ozone content is confirmed by Sinnhuber et al [19]. Since the Antarctic Oscillation is characterized by the two pressure anomalies (one of each located over Antarctic and other is placed at the 40$\left.50^{\circ} \mathrm{S}\right)$, the AAO impact on the total ozone content at the high, middle, and low latitudes should be different. To reveal how the AAO phase replacement modulates the fluctuations of ozone content in the mid-latitudes and tropics, we apply the wavelet transform to the total ozone and calculate the corre- lation coefficients as compared with same detail components of the AAOI. The largest correlation coefficients have been obtained for the detail component $D_{4}$ though for some latitudes these coefficients have opposite signs for the data of Nimbus-7 and GOME. Nevertheless, the positive correlation dependence is registered for the 5.5-year period detail components of the AAOI and total ozone in the southern mid-latitudes. On the contrary, the negative correlations are evident for the 2-3-year period detail components of the AAOI and total ozone in the southern tropics. Figure 4 illustrates these dependencies.

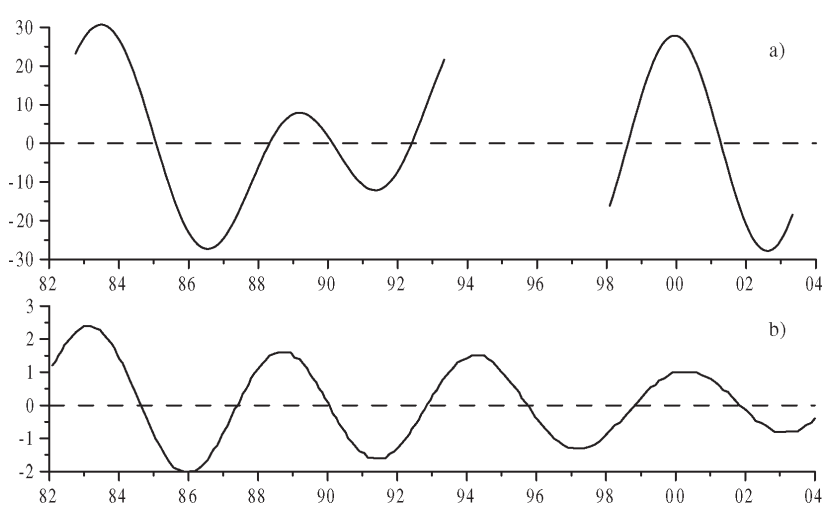

Figure 4. Detail component $D_{4}$ for total column ozone at $40-50 € \mathrm{~S}$ (a) and the AAO indices (b).

\section{Conclusion}

The advantage of using wavelet decomposition is to isolate short- and long-term components while retaining the flexibility for variability in the cycle length. Also, in addition to the revealed periodicities, this technique allows to observe the dynamic relationship between the variations of the AAO index and total ozone at the different latitudes of the Southern Hemisphere. Main findings can be shortly stated as following. The AAOI variability with periods of 5.5, 3-4, 2-3, and 1 year have most spectral power. The positive correlation dependence is registered for the 5.5-year period detail components of the AAOI and total ozone in the southern mid-latitudes. The negative correlations are evident for the 2-3-year period detail components of the AAOI and total ozone in the southern tropics.

Thus, one can be noted that the wavelet analysis represents enough the known physical behaviour of large-scale dynamics in the atmosphere and allows to detail the characteristics of this behaviour. So, the mycros data processing technology for sensing the 
total ozone content in the Earth atmosphere, based on the using observation data and the joint wavelet analysis PC programs complex "GeoMath", can be considered as quite powerful and effective tool in studying complex geosystems.

\section{References}

1. Loboda N.S., Stochastic statistical modelling of the irrigation and man-made effects on hydrological systems and water resources// Environm. Inf.Arch. - 2003. - Vol.1. - P.267273.

2. Glushkov A.V., Khokhlov V.N., Tsenenko I.A. Atmospheric teleconnection patterns and eddy kinetic energy content: wavelet analysis// Nonlin. Proc.in Geophys. - 2004. - V.11,N3. - P.285293

3. Glushkov A.V., Khokhlov V., Loboda N., Ponomarenko E., Computer Modelling Global Cycle of Carbon Dioxide in System:AtmosphereOcean// Environm. Inf.Arch. - 2003. - Vol.1P.125-130.

4. Glushkov A.V., Khokhlov V.N., Prepelitsa G.,Tsenenko I., Temporal changing of atmosphere methane content: an influence of the NAO// Optics of atm. and ocean. - 2004. - Vol.4. - C.593-598.

5. Glushkov A.V., Khokhlov V.N., Bunyakova Yu.Ya., Renorm-group approach to studying spectrum of the turbulence in atmosphere/l Meteor.Climat.Hydrol. — 2004. — №48. - C.286292.

6. Wallace J.M., Gutzler D.S., Teleconnections in the geopotential height field during the Northern Hemisphere winter// Mon. Wea. Rev. - 1081. Vol.109. - P.784-812.

7. Wanner H., Bronnimann S., Casty C. etal, North Atlantic Oscillation - concepts and studies// Surv. Geophys. - 2001. - Vol.22. - P.321-382.

8. Rogers, J.C., The association between the North Atlantic Oscillation and the Southern Oscillation in the Northern Hemisphere// Mon. Wea. Rev. 1984. - Vol.112. - P.1999-2015.

9. Gong D. - Y. and Wang S. - W. Antarctic oscillation: concept and applications// Chinese Sci. Bull. 1998-Vol.43. - P.734-738.

10. Gong D. - Y. and Wang S. - W., Definition of Antarctic oscillation index // Geophys. Res. Lett. - 1999. - Vol.43. - P.734-738.

11. Kistler R., Kalnay, E., Collins W. et al, The NCEPNCAR 50-year reanalysis: monthly means CDROM and documentation// Bull. Amer. Meteor. Soc. - 2001. - Vol.82. - P.247-267.

12. Marshall, G.J. 2002. Trends in Antarctic geopotential height and temperature: A comparison between radiosonde and NCEPNCAR reanalysis data//J. Climate. - 2002. Vol.15. - P.659-674.

13. Bronnimann S.,Luterbacher J., Schmutz C. etal, Variability of total ozone at Arosa, Switzerland, since 1931 related to atmospheric circulation indices// Geoph.Res.Lett.2000-Vol.27. - P.221316.

14. Torrence C. and Webster P.J. Interdecadal changes in the ENSO-monsoon system// J. Climate. 1999. . - Vol.12. - P.2679-2690.

15. Morlet J., Arens G., Fourgeau E. and Giard D., Wave propagation and sampling theory/l Geophysics. - 1982. — Vol.47. - p.203-236.

16. Daubechies I., Ten Lectures on Wavelets. Philadelphia: SIAM (1992).

17. Thompson D.W.J. and Wallace J.M. Annular modes in the extratropical circulation. Part I: Month-to-month variability// J. Climate. - 2000. - Vol.13. - P.1000-1016.

18. Nason G., von Sachs R., Kroisand G. Wavelet processes and adaptive estimation of the evolutionary wavelet spectrum // J. Royal Stat. Soc. - 2000. - Vol. B-62. - P. 271-292.

19. Sinnhuber B. - M., Weber M., Amankwah A. and Burrows J., Total ozone during the unusual Antarctic winter of 2002// Geophys. Res. Lett. 2003. - Vol.30. - P.1580-1585.

20. Bramstedt K., Gleason J., Loyola D. et al, Comparison of total ozone from satellite instruments GOME\&TOMS with measurements from Dobson network 1996-2000// Atm.Chem.Phys. - 2003. - Vol.3. - P.14091419. 